\title{
ANALISIS SISTEM ANTRIAN PADA LAYANAN PENGURUSAN PASPOR DI KANTOR IMIGRASI KELAS I PADANG
}

\author{
FAUZANA HILMA, HAZMIRA YOZZA, NARWEN \\ Program Studi Matematika, \\ Fakultas Matematika dan Ilmu Pengetahuan Alam, Universitas Andalas, \\ Kampus UNAND Limau Manis Padang, Indonesia, \\ email : fauzanahilma@gmail.com
}

\begin{abstract}
Abstrak. Analisis sistem antrian dilakukan pada Kantor Imigrasi Kelas I Padang, sebagai penyedia layanan pengurusan paspor bertujuan untuk menganalisis antrian yang dapat terjadi di Kantor Imigrasi tersebut. Antrian yang cukup panjang dapat memberikan kerugian bagi kedua belah pihak. Pada tugas akhir ini dilakukan analisis antrian pada tiga tahapan pelayanan di Kantor Imigrasi Kelas I Padang, yaitu Loket Antrian, Loket Berkas, Loket Foto dan Wawancara. Dari analisis yang telah dilakukan pada ketiga loket diperoleh untuk model antrian pada Loket Nomor Antrian yaitu $(G / G / 1):(G D / \infty / \infty)$, tingkat kegunaan pelayanan $(\rho)$ sebesar $32,73 \%$, probabilitas petugas tidak sedang melayani pelanggan yaitu 0.6727 , rata-rata pemohon dalam antrian 3 pemohon per 15 menit, rata-rata pelanggan dalam sistem 7,98 pemohon per 15 menit, waktu menunggu rata-rata pemohon dalam antrian sebesar 0,3120 menit dan waktu menunggu rata-rata pemohon dalam sistem sebesar 0,8108 menit. Kemudian pada Loket Berkas diperoleh model antrian yang sesuai adalah $(G / G / 3):(G D / \infty / \infty)$, tingkat kegunaan pelayanan ( $\rho$ ) sebesar 50,24\%, probabilitas petugas tidak sedang melayani pelanggan yaitu 0.5866 , rata-rata pemohon dalam antrian 1,5 pemohon per 15 menit, rata-rata pelanggan dalam sistem 9,06 pemohon per 15 menit, waktu menunggu rata-rata pemohon dalam antrian sebesar 0,2919 menit dan waktu menunggu rata-rata pemohon dalam sistem sebesar 4,6303 menit. Dan dari analisis yang telah dilakukan pada Loket Foto dan Wawancara diperoleh model yang cocok adalah $(G / G / 3):(G D / \infty / \infty)$, tingkat kegunaan pelayanan $(\rho)$ sebesar $80,88 \%$, probabilitas petugas tidak sedang melayani pelanggan yaitu 0.4003 , rata-rata pemohon dalam antrian 12,58 pemohon per 15 menit, rata-rata pelanggan dalam sistem 24,71 pemohon per 15 menit, waktu menunggu rata-rata pemohon dalam antrian sebesar 3,0964 menit dan waktu menunggu rata-rata pemohon dalam sistem sebesar 12,0569 menit.
\end{abstract}

Kata Kunci: Antrian, Model-model antrian, Pelayanan Paspor

\section{PENDAHULUAN}

Sumatera Barat dengan Ibukota provinsi Padang memiliki banyak potensi diberbagai sektor. Hal ini membuat adanya perjalanan antar negara yang dapat dilakukan oleh masyarakat. Berada langsung di bawah Direktorat Jendral Imigrasi membuat Kantor Imigrasi Kelas I Padang memiliki peran penting sebagai penyedia layanan pengurusan dokumen yang diperlukan masyarakat sebelum melakukan perjalanan ke negara lain. Pengurusan pembuatan paspor tidak pernah lepas dari masalah antrian. Untuk menghindari terjadinya kerugian saat antrian terjadi, maka digunakan 
analisis matematika yaitu analisis sistem antrian untuk melihat bagaimana bentuk antrian yang terjadi.

\section{LANDASAN TEORI}

Kantor Imigrasi Kelas I Padang berada langsung dibawah Direktorat Jenderal Imigrasi memiliki peran yang sangat penting dalam penyedia layanan pengurusan dokumen perjalanan ke luar negeri. Dalam proses pengurusan paspor, ada dua jalur yang dapat dipilih oleh seorang pemohon, yaitu jalur paspor biasa (walkin) dan jalur paspor online. Ada empat buah loket yang harus lalui oleh seorang pemohon sebelum mendapatkan paspor yaitu: Loket Nomor Antrian; Loket Berkas; Loket Foto dan Wawancara; dan Loket Pengambilan Paspor.[2]

\subsection{Peubah Acak}

\subsubsection{Distribusi Poisson}

Definisi 2.1. [1] Peubah acak diskret $X$ dikatakan berdistribusi Poisson dengan parameter $\lambda$ jika fungsi peluangnya sebagai berikut :

$$
P(X=x)=\frac{\lambda^{n} e^{-\lambda}}{x !}, x=1,2,3, \cdots
$$

\subsubsection{Distribusi Eksponensial}

Definisi 2.2. [1] Jika $X$ adalah peubah acak kontinu dengan fungsi distribusi kumulatif $P[X \leq x]=F(x)$ dimana:

$$
F(x)=1-e^{\mu x}, x>0
$$

maka $X$ berdistribusi Eksponensial dengan parameter $\mu$

\subsection{Uji Kecocokan Distribusi}

Uji kecocokan distribusi (goodness of fit) dgunakan untuk mencocokan atau menguji tingkat kesesuaian antara distribusi serangkaian harga sampel observasi dengan suatu distribusi teoritis tertentu. Salah satu uji goodness of fit adalah uji Kolmogorov Smirnov. Adapun hipotesis yang digunakan adalah sebagai berikut.

$H_{0}$ : Sampel yang diambil berasal dari populasi distribusi tertentu,

$H_{1}$ : Sampel yang diambil tidak berasal dari populasi distribusi tertentu.

Dengan taraf signifikansi 5\%. Selanjutnya akan dihitung statistik ujinya. Adapun statistik uji yang digunakan pada Uji Kolmogorov-Smirnov adalah

$$
D=\max \left|S(x)-F_{0}(x)\right|
$$

dengan:

$$
\begin{gathered}
S(x) \text { : proporsi nilai-nilai pengamatan data sampel, } \\
F_{0}(x) \text { : distribusi kumulatif dari distribusi yang dihipotesiskan. }
\end{gathered}
$$

Dengan taraf nyata $5 \%$, keputusan $H_{0}$ ditolak jika $D_{\text {hitung }}>D_{\text {tabel }}$ atau jika $P-$ Value $<\alpha$. 


\subsection{Teori Antrian}

Antrian adalah deret tunggu di dalam sebuah sistem dari unit-unit yang ingin memperoleh pelayanan dari suatu fasilitas pelayanan. Tujuan dari penggunaan teori antrian adalah untuk merancang fasilitas pelayanan, untuk mengatasi permintaan pelayanan yang berfluktuasi secara random dan menjaga keseimbangan antara biaya pelayanan [4]. Proses antrian dimulai saat pelanggan yang memerlukan pelayanan mulai datang, mereka berasal dari sebuah populasi yang disebut sumber kedatangan. kemudian masuk ke dalam antrian, mendapatkan pelayanan sampai selesai dilayani [3].

Disiplin pelayanan adalah suatu aturan dalam memilih pelanggan dari barisan antrian untuk segera dilayani. Ada beberapa disiplin antrian yang biasa digunakan pada suatu sistem antrian, yaitu First come first out (FCFS), Last come first serve (LCFS), Service in random order (SIRO), dan Priority service (PS) [?]. Desain sarana pelayanan dapat diklasifikasikan dalam channel (saluran/jalur) dan phase (tahapan) yang akan membentuk suatu struktur yang berbeda-beda. ada beberapa jenis fasilitas yang dapat ditemui diantaranya : Single channel single phase, Single channel multi phase, Multi channel single phase, Multi channel multi phase.

Pada distribusi kedatangan, biasanya digunakan distribusi peluang Poisson dimana kedatangan bersifat bebas dan tidak berpengaruh oleh kedatangan sebelum ataupun sesudahnya. Asumsi dari distribusi peluang Poisson ini adalah kedatangan pelanggan bersifat acak dan mempunyai rata-rata kedatangan sebesar $\operatorname{Lamda}(\lambda)$. Sedangkan pada distribusi pelayanan, bentuk pelayanan ditentukan oleh waktu pelayanan yaitu waktu yaang dibutuhkan untuk melayani pelanggan pada fasilitas pelayanan. Rata-rata pelayanan dapat diberi simbol $\mu$ yang merupakan jumlah pelanggan yang dapat dilayani dalam satuan waktu. sedangkan rata-rata waktu yang dipergunakan untuk melayani pelanggan diberi simbol $\frac{1}{\mu}$ unit (satuan).

\subsection{Notasi Kendall}

Menurut [6], notasi baku dalam memodelkan sistem antrian atau dikenal sebagai notasi Kendall digunakan untuk merinci ciri dari suatu antrian. Terdapat beberapa unur dasar dari suatu model antrian, yaitu :

$$
(a / b / c):(d / e / f)
$$

dimana :
a : Distribusi kedatangan;
b : Distribusi waktu pelayanan;
c : Jumlah fasilitas pelayanan $(c=1,2,3, \cdots)$;
d : Disiplin antrian, seperti FCFS, LCFS, atau SIRO;
e : Kapasitas sistem kedatangan;
f : Sumber pemanggilan. 


\subsection{Sitem Antrian Steady state}

Asumsi steady-state terpenuhi apabila $\lambda<\mu$ atau $\rho=\frac{\lambda}{\mu}<1$. Berdasarkan informasi tersebut dapat dihitung ukuran-ukuran kinerja antara lain jumlah pelanggan yang diperkirakan dalam sistem $\left(L_{s}\right)$, jumlah pelanggan yang diperkirakan dalam $\operatorname{antrian}\left(L_{q}\right)$, waktu menunggu yang diperkirakan dalam $\operatorname{sistem}\left(W_{s}\right)$, dan waktu menunggu yang diperkirakan dalam antrian $\left(W_{q}\right)[6]$.

\subsection{Model-model Antrian}

2.6.1. $(M / M / 1):(G D / \infty / \infty)$

Diasumsiakn bahwa laju kedatangan tidak bergantung pada jumlah sistem tersebut, yaitu $\lambda_{n}=\lambda$ untuk semua $n$, dengan demikian pula pelayanan tunggal dalam sistem tersebut menyelesaikan pelayanan dengan kecepatan konstan, yaitu $\mu_{n}=\mu$ untuk semua $n$. Akibatnya, model ini memiliki kedatangan dan keberangkatan Poisson dengan mean $\lambda$ dan $\mu$. Didefinisikan probabilitas untuk $n$ pelanggan, yaitu [6]:

$$
P_{n}=\rho^{n} P_{0}, n=0,1,2, \cdots
$$

Jika mengasumsikan bahwa $\rho<1$, maka

$$
P_{0}\left(\frac{1}{1-\rho}\right)=1 \text { atau } P_{0}=1-\rho
$$

Oleh karena itu diperoleh rumus umum berikut ini :

$$
P_{n}=(1-\rho) \rho^{n}, n=0,1,2, \cdots
$$

Selanjutnya akan diuraikan ukuran-ukuran kinerja sistem antrian model ini :

a. Jumlah pelanggan yang diperkirakan dalam sistem $\left(L_{s}\right)$

$$
L_{s}=\frac{\rho}{1-\rho}
$$

b. Jumlah pelanggan yang diperkirakan dalam $\operatorname{antrian}\left(L_{q}\right)$

$$
L_{q}=L_{s}-\frac{\lambda}{\mu}=\frac{\rho^{2}}{1-\rho}
$$

c. Waktu menunggu yang diperkirakan dalam sistem $\left(W_{s}\right)$

$$
W_{s}=\frac{L_{s}}{\lambda}=\frac{1}{\mu(1-\rho)}
$$

d. Waktu menunggu yang diperkirakan dalam antrian $\left(W_{s}\right)$

$$
W_{q}=\frac{L_{q}}{\lambda}=\frac{\rho}{\mu(1-\rho)}
$$


2.6.2. $(M / M / c):(G D / \infty / \infty)$

Pada model antrian ini pelanggan tiba dengan laju konstan $\lambda$ dan maksimum $c$ pelanggan dapat dilayani secara bersamaan. Laju per pelayan adalah konstan sama dengan $\mu$. Pengaruh dari penggunaan $c$ pelayan yang paralel adalah mempercepat laju pelayanan dengan memungkinkan dilakukannya beberapa pelayanan secara bersamaan. Jika $n$ adalah jumlah pelanggan dalam sistem, lebih atau sama dengan $c$, laju keberangkatan gabungan dari sarana tersebut adalah $c \mu$. Tetapi, jika $n$ kurang dari $c$, maka laju pelayanan adalah $n \mu$ [6]. Jadi dalam bentuk model yang digeneralisasi diperoleh:

$$
\begin{aligned}
& \lambda_{n}=\lambda, \text { untuk semua } n \geq 0, \\
& \mu_{n}=\left\{\begin{array}{l}
n \mu ; n<c, \\
c \mu ; n \geq c,
\end{array}\right.
\end{aligned}
$$

Dengan memisalkan $\rho=\frac{\lambda}{\mu}$, nilai $P_{0}$ ditentukan dengan nilai $\sum_{n=0}^{\infty} P_{n}=1$ sehingga :

$$
P_{0}=\left\{\sum_{n=0}^{c-1} \frac{\rho^{n}}{n !}+\frac{c \rho^{c}}{c !(c-\rho)}\right\}^{-1}, \quad \frac{\rho}{c}<1
$$

Dengan demikian

$$
P_{n}=\frac{\lambda^{n}}{c ! c^{n-c} \mu^{n}} P^{0}
$$

Selanjutnya akan diuraikan ukuran-ukuran kinerja sistem antrian model ini.

a. Jumlah pelanggan yang diperkirakan dalam $\operatorname{antrian}\left(L_{q}\right)$

$$
L_{q}=\frac{\rho^{c+1}}{(c-1) !(c-\rho)^{2}} P_{0}
$$

b. Jumlah pelanggan yang diperkirakan dalam sistem $\left(L_{s}\right)$

$$
L_{s}=L_{q}+\rho
$$

c. Waktu menunggu yang diperkirakan dalam antrian $\left(W_{s}\right)$

$$
W_{q}=\frac{L_{q}}{\lambda}
$$

d. Waktu menunggu yang diperkirakan dalam sistem $\left(W_{s}\right)$

$$
W_{s}=\frac{L_{s}}{\lambda}
$$

2.6.3. $(G / G / c):(G D / \infty / \infty)$

Ukuran-ukuran kinerja sistem pada model General ini mengikuti ukuran kinerja pada model $(M / M / c):(G D / \infty / \infty)$, terkecuali untuk perhitungan jumlah pelanggan yang diperkirakan dalam antrian $L_{q}$. Rumus untuk mencari ukuran-ukuran kinerja pada model $(G / G / c):(G D / \infty / \infty)$ adalah sebagai berikut [3]: 
a. Jumlah pelanggan yang diperkirakan dalam antrian $\left(L_{q}\right)$

$$
L_{q}=\frac{\rho^{c+1}}{(c-1) !(c-\rho)^{2}} P_{0} \frac{\mu^{2} v(t)+v\left(t^{\prime}\right) \lambda^{2}}{2}
$$

dimana :

$$
\begin{gathered}
v(t)=\left(\frac{1}{\mu^{2}}\right)^{2} \\
v\left(t^{\prime}\right)=\left(\frac{1}{\lambda^{2}}\right)^{2},
\end{gathered}
$$

dengan

$$
\begin{gathered}
v(t) \text { : adalah varian dari waktu pelayanan, } \\
v\left(t^{\prime}\right) \text { : adalah varian dari jumlah kedatangan. }
\end{gathered}
$$

b. Jumlah pelanggan yang diperkirakan dalam sistem $\left(L_{s}\right)$

$$
L_{s}=L_{q}+\rho
$$

c. Waktu menunggu yang diperkirakan dalam antrian $\left(W_{s}\right)$

$$
W_{q}=\frac{L_{q}}{\lambda}
$$

d. Waktu menunggu yang diperkirakan dalam sistem $\left(W_{s}\right)$

$$
W_{s}=\frac{L_{s}}{\lambda}
$$

\section{Metode Penelitian}

Data yang digunakan dalam penelitian ini adalah data primer yang diperoleh melalui pengamatan di kantor Imigrasi selama lima hari kerja yaitu 26, 29, 31 Agustus dan 1-2 September 2016. Dalam satu hari penelitian akan dilakukan mulai pukul 07.1512 .00 WIB . Pengamatan hanya dilakukan pada tiga loket pada kantor Imigrasi Kelas I Padang yaitu Loket Antrian, Loket Berkas, dan Loket Foto Wawancara. Diasumsikan bahwa proses kedatangan dan proses keberangkatan pemohon dalam pelayanan paspor di masing-masing loket tidak berubah dan dapat mewakili populasi di hari lainnya. Adapun langkah-langkah penelitian dan analisis data yang dilakukan adalah:

1. Menghitug data jumlah kedatangan dan waktu pelayanan pelanggan disetiap loket.

2. Menguji apakah data yang didapatkan sudah memenuhi kondis steady state.

3. Melakukan uji kecockan distribusi terhadap distribusi kedatangan dan distribusi pelayanan.

4. Menentukan model yang sesuai untuk setiap loket.

5. Menghitung ukuran-ukuran kinerja sistem dari setiap loket. 


\section{Pembahasan}

\subsection{Analisis dan Pembahasan pada Loket Nomor Antrian}

Pada Loket Antrian, telah dilakukan pencatatn waktu masuk dan waktu keluar pemohon setiap 15 menit. Dari hasil yang telah diolah diperoleh tingkat kegunaan pelayanan $(\rho)$ adalah $32,73 \%$, yang mana menunjukkan pelayanan pada Loket antrian sudah memenuhi asumsi steady state. Kemudian dilakukan uji diatribusi terhadap kedatangan dan waktu pelayanan. Dari uji yang telah dilakukan diperoleh hasil bahwa diatribusi kedatangan pada Loket Antrian tidak berdistribusi Poisson dan distribusi pelayanan pada Loket Antrian tidak berdistribusi Eksponensial. Sehingga diperoleh model yang sesuai untuk loket ini adalah model $(G / G / 1):(G D / \infty / \infty)$.

Berdasarkan model yang sudah kita dapatkan, maka dapat dihitung ukuranukuran kinerja sistem antrian pada loket ini. Untuk probabilitas petugas tidak sedang melayani pemohon $\left(P_{0}\right)$ adalah 0.6727 , jumlah pelanggan yang diperkirakan dalam $\operatorname{antrian}\left(L_{q}\right)$ adalah 3 pemohon per 15 menit, jumlah pelanggan yang diperkirakan dalam sistem $\left(L_{s}\right)$ adalah 7,89 pemohon per 15 menit, waktu menunggu yang diperkirakan dalam antrian $\left(W_{q}\right)$ adalah 0.3120 menit, dan waktu menunggu yang diperkirakan dalam sistem $\left(W_{s}\right)$ adalah 0,8108 menit.

\subsection{Analisis dan Pembahasan pada Loket Berkas}

Pada Loket Berkas, terdapat tiga buah loket yang beroperasi. Dari hasil pengolahan data terhadap waktu datang dan waktu keluar pemohon diperoleh tingkat kegunaan pelayanan pada loket ini adalah sebesar 50,24 \%, sehingga dapat dikatakan bahwa sistem antrian pada loket ini sudah memenuhi kondisi steady state. Kemudian untuk uji distribusi yang telah dilakukan diperoleh distribusi kedatangan pada loket berkas ini tidak berdistribusi Poisson dan distribusi pelayanannya tidak berdistribusi eksponensial. Sehingga diperoleh model antrian yang cocok untuk loket ini adalah adalah model $(G / G / 3):(G D / \infty / \infty)$.

Berdasarkan model yang sudah kita dapatkan, maka dapat dihitung ukuranukuran kinerja sistem antrian pada loket berkas ini. Untuk probabilitas petugas tidak sedang melayani pemohon $\left(P_{0}\right)$ adalah 0.5866 , jumlah pelanggan yang diperkirakan dalam $\operatorname{antrian}\left(L_{q}\right)$ adalah 1.5 pemohon per 15 menit, jumlah pelanggan yang diperkirakan dalam sistem $\left(L_{s}\right)$ adalah 9.1 pemohon per 15 menit, waktu menunggu yang diperkirakan dalam antrian $\left(W_{q}\right)$ adalah 0.2919 menit, dan waktu menunggu yang diperkirakan dalam sistem $\left(W_{s}\right)$ adalah 4.6303 menit.

\subsection{Analisis dan Pembahasan pada Loket Foto dan Wawancara}

Pada Loket Foto dan Wawancara, terdapat empat buah loket yang tersedia. Namun pada saat penelitian dilakukan, hanya ada 3 loket yang beroperasi dikarenkan terdapat perbaikan alat yang digunakan pada salh satu loket. Dari pengolahan data terhadap waktu datang dan waktu keluar pemohon diperoleh tingkat kegunaan pelayanan pada loket ini adalah sebesar $80.88 \%$, sehingga dapat dikatakan bahwa sistem antrian pada loket ini sudah memenuhi kondisi steady state. Kemudian un- 
tuk uji distribusi yang telah dilakukan diperoleh distribusi kedatangan pada loket berkas ini tidak berdistribusi Poisson dan distribusi pelayanannya tidak berdistribusi eksponensial. Sehingga diperoleh model antrian yang cocok untuk loket ini adalah adalah model $(G / G / 3):(G D / \infty / \infty)$.

Berdasarkan model yang sudah kita dapatkan, maka dapat dihitung ukuranukuran kinerja sistem antrian pada loket berkas ini. Untuk probabilitas petugas tidak sedang melayani pemohon $\left(P_{0}\right)$ adalah 0.4033 , jumlah pelanggan yang diperkirakan dalam $\operatorname{antrian}\left(L_{q}\right)$ adalah 12,6 pemohon per 15 menit, jumlah pelanggan yang diperkirakan dalam sistem $\left(L_{s}\right)$ adalah 24,7 pemohon per 15 menit , waktu menunggu yang diperkirakan dalam antrian $\left(W_{q}\right)$ adalah 3.0964 menit, dan waktu menunggu yang diperkirakan dalam sistem $\left(W_{s}\right)$ adalah 12.0569 menit.

\section{Kesimpulan}

Dari hasil analisis sistem antrian yang telah dilakukan terhadap loket-loket pelayanan di Kantor Imigrasi Kelas I Padang dapat disimpulkan bahwa sistem antrian disetiap loket dapat dikatakan sudah baik. Hal ini dapat kita lihat dari nilai tingkat kegunaan pelayanan $(\rho)$ dari setiap loket yang sudah memenuhi kondisi steady state dan nilai-nilai dari waktu menunggu pemohon disetiap loket yang tidak teelalu lama.

\section{Daftar Pustaka}

[1] Gross, D dan Harris C. M. 1998. Fndamental of Queing Theory. Third Edition. USA : MC Graw Hill.

[2] Kantor Imigrasi Kelas I Padang. 2014. Profil Kantor Imigrasi Kelas I Padang.www.imigrasipadang.com. 9 Agustus 2016

[3] Levin, Ricarh I., D. Rubin, J. Stinson dan E. Gardner. 1985. Quantitative Approaches to Management. Seven Edition. Terjemahan Nurtanto. PT Rajagrafindo Persada : Jakarta.

[4] Pangestu S., Marwan A., T. H. Handoko. 1983 Dasar-dasar Operation Research. Edisi 2. BPFE : Yogyakarta.

[5] Taha, H. A., 1996 Riset Operasi Jilid 2. Binarupa Aksara : Jakarta.

[6] Sinalungga, S. 2008. Pengantar Teknik Industri. Graha Ilmu : Yogyakarta. 